Vegetalika. 2018. 7(3): 1-15

\title{
Produksi dan Kadar Flavonoid Daun Sambung Nyawa (Gynura procumbens (Lour.) Merr.) pada Tiga Fase Agroforestri
}

\author{
Production and Flavonoid Contents of Sambung Nyawa Leaves \\ (Gynura procumbens (Lour.) Merr.) in Three Stages of Agroforestry
}

\author{
Deborah Gita Sakinah, Eka Tarwaca Susila Putra*), Rohlan Rogomulyo \\ Departemen Budidaya Pertanian, Fakultas Pertanian, Universitas Gadjah Mada \\ *) Penulis untuk koresponden Email: ekatarwaca79@gmail.com
}

\begin{abstract}
Sambung nyawa (Gynura procumbens (Lour.) Merr.) is one of medicinal plant that have become pharmaceutical industry material whose demand increase along with the public awareness of the herbal medicine utilization. Planting in agroforestry can be a solution to the limitations of agricultural land and one of the efforts to increase the production of sambung nyawa. This research was conducted to find out the optimum of agroforestry stages for production of sambung nyawa. The research had been conducted on Nglanggeran zone, Patuk, Gunung Kidul and arranged in over site single factor with three replication. The single factor was development levels of agroforestry: early, middle, and advanced stage. The results showed that "Sambung Nyawa" have wide adaptability if cultivated under agroforestry because it has the same growth rate, productivity, and quality when cultivated in the early, middle, and advanced developments stages of agroforestry. The quality of "Sambung Nyawa" leaves that produced in the early, middle, and advanced development stages of agroforestry were quite good and can meet with the Indonesian pharmacopoeia standards, especially from the aspect of flavonoid contents. The flavonoid contents of "Sambung Nyawa" that produced by early, middle, and advanced development stages of agroforestry were $1.42,1.72$, and $1.18 \% \mathrm{w} / \mathrm{w}$, respectively.
\end{abstract}

Keywords : agroforestry, sambung nyawa, flavonoids

\section{INTISARI}

Sambung nyawa (Gynura procumbens (Lour.) Merr.) merupakan salah satu tanaman obat yang telah menjadi bahan baku industri farmasi yang permintaannya akan semakin meningkat seiring dengan kesadaran masyarakat akan pentingnya pemanfaatan obat herbal. Penanaman di agroforestri dapat menjadi solusi atas keterbatasan lahan pertanian dan salah satu upaya untuk meningkatkan produksi sambung nyawa. Penelitian ini bertujuan untuk mengetahui fase perkembangan agroforestri yang paling optimal bagi produksi sambung nyawa. Penelitian dilakukan di zona Nglanggeran, Kecamatan Patuk, Kabupaten Gunung Kidul dan disusun dalam rancangan over site faktor tunggal dengan tiga kali ulangan. Faktor tunggal berupa 
fase perkembangan agroforestri yaitu fase awal, fase tengah, dan fase lanjut. Hasil penelitian memberikan informasi bahwa tanaman sambung nyawa memiliki daya adaptasi yang cukup luas jika diusahakan dengan konsep agroforestri karena memiliki laju pertumbuhan, produktivitas, serta kualitas hasil yang sama ketika dibudidayakan pada agroforestri fase awal, tengah, dan lanjut. Kualitas daun sambung nyawa yang dihasilkan pada agroforestri fase awal, tengah, dan lanjut cukup baik dan dapat memenuhi standar Farmakope Herbal Indonesia, khususnya dari aspek kadar flavonoid. Secara berturut-turut kadar flavonoid daun sambung nyawa yang dihasilkan pada fase awal, tengah, dan lanjut adalah 1,42; 1,72; dan 1,18\%b/b.

Kata kunci: agroforestri, sambung nyawa, flavonoid

\section{PENDAHULUAN}

Kesadaran masyarakat untuk hidup lebih sehat dengan konsep kembali ke alam berkontribusi pada kenaikan pemanfaatan obat-obatan berbasis produk tanaman. Permintaan yang meningkat terhadap obat berbasis produk tanaman menyebabkan kelangkaan barang tersebut di pasaran. Salah satu produk tanaman yang pada saat ini cukup langka pasokannya pada hal permintaannya tinggi adalah daun sambung nyawa yang dihasilkan oleh tanaman sambung nyawa (Gynura procumbens (Lour.) Merr). Obat berbahan daun sambung nyawa banyak dipakai sebagai upaya preventif dan kuratif untuk penyakit kanker, darah tinggi, ginjal, dan kolestrol (Hew et al., 2013). Pada saat ini, daun sambung nyawa telah dimanfaatkan sebagai bahan baku industri farmasi, dan penelitian mengenai khasiatnya dalam kesehatan pun semakin meningkat, bahkan telah terdaftar sebagai tanaman herbal bernilai tinggi dibawah inisiatif Agricutural National Key Economic Area (NKEA) untuk subsektor herbal pada tahun 2010 (MOA, 2015). Mengingat potensi dan peluang pasar yang cukup besar, maka kegiatan budidaya $G$. procumbens penting dilakukan untuk menjaga kestabilan ketersediaan bahan baku dan terhindar dari tindakan yang merugikan seperti pemalsuan bahan obat tradisional.

Tumbuhan obat, termasuk sambung nyawa, pada umumnya banyak ditanam oleh masyarakat, atau tumbuh secara liar, namun tidak diproduksi dalam skala yang besar. Hal ini disebabkan oleh semakin terbatasnya lahan pertanian, bersaing dengan komoditas yang kepentingannya lebih mendesak seperti komoditas pangan dan perkebunan. Salah satu cara untuk meningkatkan skala produksi sambung nyawa ialah sistem agroforestri. Agroforestri merupakan suatu sistem yang mengkombinasikan tumbuhan berkayu dan tanaman pertanian, dan atau hewan dan atau ikan, yang prinsipnya memanfaatkan lahan sela diantara pertanaman tumbuhan berkayu. Agroforestri dapat dibedakan menjadi tiga tingkat perkembangan berdasarkan struktur 
dan komponen penyusunnya (Suryanto dkk., 2005): (a) Agroforestri awal, yaitu model agroforestri dengan ruang horizontal untuk tanaman semusim lebih dari $50 \%$ (b) Agroforestri pertengahan, yaitu model agroforestri yang mengarah pada pengurangan bidang bidang olah karena pohon memberikan naungan sehingga luasan bidang olah menjadi $25-50 \%$, (c) Agroforestri lanjut, merupakan proses lanjutan dari agroforestri pertengahan, intensitas cahaya yang akan diterima bidang olah kurang dari $30 \%$ sehingga model lanjutnya sangat tergantung pada jenis tanaman pengkaya.

Penelitian mengenai tumbuhan obat pada sistem agroforestri masih terbatas, mengingat tidak semua tumbuhan obat memiliki ketahanan pada naungan. Sambung nyawa termasuk tumbuhan obat yang tahan naungan, dan idealnya mendapat $60 \%$ sinar matahari agar tidak menghasilkan daun yang keras (Suharmiati, 2003). Hal ini telah dibuktikan pula pada penelitian oleh Dainy (2006) adanya produksi daun yang lebih baik pada tingkat naungan 55\% dengan kadar flavonoid terbanyak. Pemanfaatan sistem agroforestri untuk penanaman sambung nyawa memiliki peluang besar untuk meningkatkan pendapatan petani karena nilai ekonominya yang tinggi sebagai bahan baku industri farmasi. Oleh karena itu, penelitian terkait pertumbuhan dan hasil sambung nyawa pada sistem agroforestri dirasa penting untuk menemukan fase perkembangan agroforestri yang paling optimal bagi pertumbuhan dan produksi flavonoid pada sambung nyawa.

\section{BAHAN DAN METODE PENELITIAN}

Penelitian dilaksanakan pada bulan Mei 2017 - Oktober 2017 di lahan agroforestri Desa Nglanggeran, Kecamatan Patuk, Gunung Kidul, D.I. Yogyakarta. Bahan yang digunakan berupa bibit hasil stek sambung nyawa (Gynura procumbens (Lour.) Merr) umur 1 bulan yang diperoleh dari Kebun Merapi Farma Kaliurang, Yogyakarta, pupuk kandang, dan pestisida. Peralatan yang diperlukan antara lain cangkul, gatul, sabit, label, meteran, alat tulis, penggaris, oven, timbangan, area meter, tali rafia, luxmeter, SPAD 502, spectronic 21D, mikroskop, OptiLab, kutek, isolasi transparan, dan termohygrometer.

Penelitian disusun dalam rancangan over site dengan satu faktor yaitu fase perkembangan agroforestri yang diulang sebanyak 3 kali. Faktor yang digunakan adalah fase perkembangan agroforestri yaitu fase awal, fase tengah dan fase lanjut. Masing-masing perlakuan di setiap ulangan menggunakan petak percobaan, dimana setiap petak terdapat 3 bedengan dengan 20 tanaman pada tiap bedengannya. Terdapat 3 petak percobaan, sehingga secara keseluruhan terdapat 9 bedengan dan 
Deborah Gita Sakinah et al., / Vegetalika. 2018. 7(3): 1-15

180 tanaman. Setiap bedengan dipilih 3 tanaman sebagai tanaman sampel yang akan dipanen pada 16 mspt. Data yang diperoleh dianalisis varian (ANOVA) 5\%, apabila ada beda nyata dilanjutkan dengan uji DMRT. Selain itu dilakukan analisis regresi antara suhu udara, kelembapan udara, dan intensitas cahaya matahari dengan semua parameter uji. Setelah diperoleh nilai $\mathrm{P}<0,05$ maka selanjutnya data divisualisasikan menggunakan grafik regresi.

\section{HASIL DAN PEMBAHASAN}

Fase perkembangan agroforestri memberi karakteristik tersendiri pada mikroklimat di dalamnya. Semakin lanjut fase perkembangnya, intensitas cahaya matahari dan suhu udara semakin menurun, sedangkan kelembapan udaranya semakin meningkat. Hanya saja agroforestri fase tengah memiliki suhu dan kelembapan yang kadang cenderung tidak berbeda nyata jika dibandingkan dengan salah satu dari fase awal atau akhir (Tabel 1). Lokasi penelitian memiliki rerata intensitas cahaya yang berkisar antara 1.072-76.781 lux, rerata suhu udara 27,42$32,45^{\circ} \mathrm{C}$, dan rerata kelembapan udara 50,15-67,15\% (Tabel 1). Winarto (2003) dalam Wijayanti (2012) menyatakan bahwa sambung nyawa tumbuh dengan baik pada suhu udara berkisar $20-30^{\circ} \mathrm{C}$, intensitas cahaya $40-50 \%$.

Tabel 1. Suhu udara, kelembapan udara, dan intensitas cahaya selama penelitian

\begin{tabular}{|c|c|c|c|c|c|c|}
\hline \multirow{2}{*}{ Fase Agroforestri } & \multicolumn{6}{|c|}{ Suhu Udara $\left({ }^{\circ} \mathrm{C}\right)$} \\
\hline & Pagi & & Siang & & Sore & \\
\hline Awal & 29,00 & a & 32,45 & a & 30,13 & a \\
\hline Tengah & 28,08 & $b$ & 31,48 & $b$ & 29,91 & a \\
\hline Lanjut & 27,42 & C & 31,21 & $\mathrm{~b}$ & 29,45 & $b$ \\
\hline Koefisien Keragaman (\%) & 0,78 & & 1,00 & & 0,56 & \\
\hline \multirow{2}{*}{ Fase Agroforestri } & \multicolumn{6}{|c|}{ Kelembapan Udara (\%) } \\
\hline & Pagi & & Siang & & Sore & \\
\hline Awal & 61,94 & C & 50,15 & b & 54,67 & $b$ \\
\hline Tengah & 63,79 & $b$ & 50,25 & $b$ & 55,19 & b \\
\hline Lanjut & 67,15 & a & 51,35 & a & 56,52 & a \\
\hline Koefisien Keragaman (\%) & 1,01 & & 0,74 & & 0,77 & \\
\hline \multirow{2}{*}{ Fase Agroforestri } & \multicolumn{6}{|c|}{ Intensitas Cahaya (lux) } \\
\hline & Pagi & & Siang & & Sore & \\
\hline Awal & 61536 & a & 76781 & a & 31116 & a \\
\hline Tengah & 36643 & $b$ & 45835 & $b$ & 22379 & $a b$ \\
\hline Lanjut & 16508 & $\mathrm{C}$ & 20615 & $\mathrm{C}$ & 10792 & $\mathrm{~b}$ \\
\hline Koefisien Keragaman (\%) & 13,52 & & 15,43 & & 27,36 & \\
\hline
\end{tabular}

Keterangan: angka rerata yang diikuti huruf yang sama menunjukkan tidak adanya beda nyata pada uji DMRT pada taraf $5 \%$

Besar presentase penaungan oleh tanaman penegak pada tiap fase agroforestri juga perlu diketahui. Hani dan Suryanto (2014) menyatakan fase 
agroforestri awal memiliki penaungan $<50 \%$, agroforestri pertengahan memiliki penaungan $50-70 \%$, sedangkan pada agroforestri lanjut memiliki penaungan $>70 \%$. Tabel 2. menunjukkan agroforestri fase awal pada pagi dan siang hari memiliki penaungan $<30 \%$ dengan penerusan cahaya sedangkan pada sore hari $55,97 \%$, dengan penerusan cahaya $<50 \%$. Pada sore hari, matahari sudah mulai condong ke arah barat dan tertutup oleh tegakan dalam agroforestri, sehingga cahaya yang diteruskan lebih sedikit dan efek penaungan yang ditimbulkan lebih daripada pada saat pagi dan siang. Fase tengah memiliki penaungan antara 50,12-68,33\% dengan penerusan cahaya masih dalam kisaran $30-50 \%$, dan fase lanjut memiliki penaungan $77,56-84,73 \%$ dengan penerusan cahaya $15,27-22,44 \%$.

Tabel 2. Sekapan cahaya (SC) dan Cahaya yang diteruskan (CT) pada agroforestri fase awal, tengah, dan lanjut

\begin{tabular}{ccccccc}
\hline Fase & \multicolumn{2}{c}{ Sekapan Cahaya $(\%)$} & \multicolumn{3}{c}{ Cahaya yang Diteruskan (\%) } \\
\cline { 2 - 7 } agroforestri & pagi & siang & sore & pagi & siang & sore \\
\hline awal & 28,44 & 16,44 & 55,97 & 71,56 & 83,56 & 44,03 \\
tengah & 57,39 & 50,12 & 68,33 & 42,61 & 49,88 & 31,67 \\
lanjut & 80,80 & 77,56 & 84,73 & 19,20 & 22,44 & 15,27 \\
\hline
\end{tabular}

Tanah di lokasi penelitian memiliki tekstur liat dengan fraksi liat sebesar 64\%, fraksi debu 20\% dan fraksi pasir 16\% (Tabel 3). Tabel 4 dan 5 menunjukkan sifat kimia tanah sebelum dan sesudah tanam. Baik pada sebelum dan sesudah tanam, tanah memiliki pH agak masam dengan kadar bahan organik yang rendah. Sesuai dengan yang dinyatakan oleh Winarto (2003) tanaman ini mampu tumbuh di hampir segala jenis tanah seperti tanah gambut, vulkanik, dan podsolik dengan kisaran $\mathrm{pH}$ tanah 5,57. C-organik menunjukkan kadar bahan organik yang terkandung dalam tanah. Kadar C-organik dalam tanah pada ketiga fase agroforestri memiliki kriteria yang rendah, akan tetapi terlihat fase agroforestri lanjut mengandung C-organik yang paling tinggi, diikuti fase tengah, kemudian paling rendah fase awal. Agroforestri fase lanjut memiliki kepadatan populasi penegak yang lebih tinggi daripada fase yang lain, sehingga daun yang gugur dan jatuh ke tanah dan menjadi sumber bahan organik jumlahya akan lebih banyak.

Sebelum tanam, presentase $\mathrm{N}$-total dalam tanah sangat rendah, akan tetapi setelah tanam pada fase agroforestri awal dan tengah menjadi $0,13 \%$ dan $0,11 \%$ yang termasuk dalam kriteria rendah, sedangkan agroforestri lanjut memiliki presentase $\mathrm{N}$ total $0,07 \%$ yang termasuk dalam kriteria sangat rendah (Tabel 5). Hal ini dikarenakan kadar C-organik yang lebih tinggi pada agroforestri fase lanjut, di mana mikroorganisme tanah membutuhkan $\mathrm{N}$ yang lebih tinggi pula untuk melakukan dekomposisi, dan sisanya diserap oleh tanaman. Pada agroforestri fase lanjut, $\mathrm{N}$ 
Deborah Gita Sakinah et al., / Vegetalika. 2018. 7(3): 1-15

sangat dibutuhkan oleh tanaman terutama untuk pembentukan klorofil yang lebih banyak untuk meningkatkan efisiensi penyerapan cahaya matahari pada daun (Tabel 7). Terlebih $\mathrm{N}$ dalam bentuk nitrat pada tanah sangat mobil sehingga mudah mengalami pencucian.

Terjadi penurunan kriteria $\mathrm{P}_{2} \mathrm{O}_{5}$ dan $\mathrm{K}_{2} \mathrm{O}$ potensial dalam tanah dari sebelum tanam ke sesudah tanam (Tabel 4 dan 5), Beda halnya dengan kadar Ca dan Mg yang tidak mengalami perubahan, tetap tinggi baik sebelum maupun sesudah tanam. Penurunan ketersediaan $\mathrm{P}_{2} \mathrm{O}_{5}$ dan $\mathrm{K}_{2} \mathrm{O}$ mengindikasikan adanya penyerapan hara dalam tanah oleh tanaman. Status ketersediaan $\mathrm{Ca}$ dan $\mathrm{Mg}$ yang tidak berubah dari sebelum penanaman hingga setelah penanaman ini menunjukkan kemungkinan bahwa $\mathrm{Ca}$ dan $\mathrm{Mg}$ dalam tanah tidak berkontribusi signifikan pada pertumbuhan sambung nyawa. Setiap tanaman dapat melakukan seleksi unsur hara yang akan diserap sehingga unsur $\mathrm{Ca}$ dan $\mathrm{Mg}$ diduga tidak dibutuhkan tanaman sambung nyawa dalam jumlah yang signifikan sehingga kadarnya dalam tanah tidak banyak berubah. Nilai KTK yang ada dalam lokasi penelitian tergolong sangat tinggi pada ketiga fase. Tan (1991) menyatakan bahwa kapasitas tukar kation tanah adalah kemampuan koloid tanah dalam menjerap dan mempertukarkan kation, sehingga semakin tinggi nilai KTK maka semakin banyak unsur hara yang dijerap dan tersedia bagi tanaman. Kapasitas tukar kation tanah yang tinggi dapat mengurangi kehilangan unsur hara yang ditambahkan melalui pemupukan, atau dari hasil mineralisasi bahan organik tanah, sehingga bahan organik tanah dapat meningkatkan efisiensi pemupukan (Suprayogo, 2003).

Tabel 3. Analisis tekstur tanah sebelum penelitian

\begin{tabular}{cccc}
\hline \multicolumn{3}{c}{ Tekstur } & \multirow{2}{*}{ Kelas } \\
\cline { 1 - 3 } Pasir (\%) & Debu (\%) & Lempung (\%) & \\
\hline 16 & 20 & 64 & Liat \\
\hline
\end{tabular}

Catatan: Kelas berdasarkan segitiga tekstur USDA (Brady, 1974)

Tabel 4. Analisis sifat kimia tanah sebelum penanaman tanaman sambung nyawa

\begin{tabular}{clll}
\hline No & \multicolumn{1}{c}{ Keterangan } & Nilai & \multicolumn{1}{c}{ Kriteria } \\
\hline 1 & pH tanah $\left(\mathrm{H}_{2} \mathrm{O}\right)$ & 5,51 & Agak masam \\
2 & C-organik $(\%)$ & 1,23 & Rendah \\
3 & N-total $(\%)$ & 0,06 & Sangat rendah \\
4 & $\mathrm{P}_{2} \mathrm{O}_{5}$ potensial $(\mathrm{mg} / 100 \mathrm{~g})$ & 42,00 & Tinggi \\
5 & $\mathrm{~K} 2 \mathrm{O}$ potensial $(\mathrm{mg} / 100 \mathrm{~g})$ & 24,00 & Sedang \\
6 & $\mathrm{Ca}-\mathrm{dd}(\mathrm{me} / 100 \mathrm{~g})$ & 14,01 & Tinggi \\
7 & $\mathrm{Mg}$-dd $(\mathrm{me} / 100 \mathrm{~g})$ & 2,21 & Tinggi \\
8 & Kadar lengas tanah $(\%)$ & 31,30 & \\
\multicolumn{4}{l}{ Catatan : Kriteria menurut Hardjowigeno (1995) }
\end{tabular}


Deborah Vegetalika. 2018. 7(3): 1-15

Tabel 5. Analisis tanah setelah penanaman sambung nyawa pada tiga fase agroforestri

\begin{tabular}{|c|c|c|c|c|c|c|c|}
\hline \multirow{2}{*}{ No } & \multirow{2}{*}{ Parameter } & \multicolumn{6}{|c|}{ Fase Agroforestri } \\
\hline & & Awal & Kriteria & Tengah & Kriteria & Lanjut & Kriteria \\
\hline 1 & $\mathrm{pH}$ tanah $\left(\mathrm{H}_{2} \mathrm{O}\right)$ & 5,52 & Agak masam & 5,92 & $\begin{array}{l}\text { Agak } \\
\text { masam }\end{array}$ & 6,01 & $\begin{array}{l}\text { Agak } \\
\text { masam }\end{array}$ \\
\hline 2 & C-organik (\%) & 1,05 & Rendah & 1,20 & Rendah & 1,35 & Rendah \\
\hline 3 & $\mathrm{~N}$-total (\%) & 0,13 & Rendah & 0,11 & Rendah & 0,07 & $\begin{array}{l}\text { Sangat } \\
\text { rendah }\end{array}$ \\
\hline 4 & $\begin{array}{l}\mathrm{P}_{2} \mathrm{O}_{5} \text { potensial } \\
(\mathrm{mg} / 100 \mathrm{~g})\end{array}$ & 25,00 & Sedang & 31,00 & Sedang & 30,00 & Sedang \\
\hline 5 & $\begin{array}{l}\mathrm{K}_{2} \mathrm{O} \text { potensial } \\
(\mathrm{mg} / 100 \mathrm{~g})\end{array}$ & 22,00 & Sedang & 19,00 & Rendah & 18,00 & Rendah \\
\hline $\begin{array}{l}6 \\
7\end{array}$ & $\begin{array}{l}\text { Ca-dd (me/100g) } \\
\text { Mg-dd (me/100g) }\end{array}$ & $\begin{array}{c}14,59 \\
3,35\end{array}$ & $\begin{array}{l}\text { Tinggi } \\
\text { Tinggi }\end{array}$ & $\begin{array}{l}16,73 \\
2,91\end{array}$ & $\begin{array}{l}\text { Tinggi } \\
\text { Tinggi }\end{array}$ & $\begin{array}{l}16,9 \\
2,64\end{array}$ & $\begin{array}{l}\text { Tinggi } \\
\text { Tinggi }\end{array}$ \\
\hline 8 & KTK (me/100g) & 55,26 & Sangat tinggi & 57,23 & $\begin{array}{c}\text { Sangat } \\
\text { tinggi }\end{array}$ & 57,75 & $\begin{array}{c}\text { Sangat } \\
\text { tinggi }\end{array}$ \\
\hline
\end{tabular}

Adapun kadar lengas tanah sebelum penanaman sebesar 31,3\% (Tabel 4) dan setelah penanaman pada fase agroforestri awal, tengah, dan lanjut berturut-turut yaitu $25,57 \%, 29,04 \%$, dan $36,68 \%$ (Tabel 6) yang secara statistik tidak memiliki perbedaan nyata. Tidak adanya perbedaan nyata ini dapat dipengaruhi oleh beberapa faktor seperti topografi lahan penelitian yang tidak rata dan miring di mana agroforestri fase lanjut berada pada lokasi yang lebih tinggi daripada fase tengah dan fase awal sedangkan fase awal berada pada lahan yang paling rendah dengan banyak cekungan pada permukaan tanahnya sehingga air banyak terkumpul dan kadar lengas tanah menjadi tidak berbeda nyata. Kadar lengas tanah dipengaruhi secara nyata oleh kelembapan udara (Gambar 1), di mana peningkatan kelembapan udara akan diikuti dengan peningkatan kadar lengas tanah. Kelembapan udara merupakan salah satu unsur iklim mikro yang dapat dipengaruhi oleh vegetasi yang tumbuh di atas tanah, sama halnya dengan kemampuan tanah dalam menyimpan air. Keberadaan tanaman yang tumbuh di atas tanah dapat memengaruhi kemampuan tanah untuk menyimpan air, adanya naungan pohon dapat mengurangi laju evaporasi dan transpirasi tanaman yang ada di bawahnya dan akar pohon dapat meningkatkan infiltrasi air ke dalam tanah dan menjaga kadar lengas tanah (Kurniawan dkk., 2012). Fase agroforestri awal yang minim tegakan dengan jarak pertanaman yang jauh dari tegakan dapat menjadi penyebab rendahnya kadar lengas tanah. Sebaliknya, fase agroforestri lanjut dengan populasi tegakan yang tinggi dan jarak tegakan yang rapat menyebabkan kadar air yang berlimpah dalam tanah, walaupun ketiganya secara statistik tidak berbeda nyata. 
Deborah Gita Sakinah et al., / Vegetalika. 2018. 7(3): 1-15

Tabel 6. Analisis kadar lengas tanah tanah jeluk 0-30 cm selama penelitian

\begin{tabular}{|c|c|c|}
\hline Fase Agroforestri & Kadar lenga & s tanah \\
\hline awal & 25,57 & $a$ \\
\hline tengah & 29,04 & a \\
\hline lanjut & 36,68 & a \\
\hline Koefisien Keragaman (\%) & 20,18 & \\
\hline
\end{tabular}

Keterangan: angka rerata yang diikuti huruf yang sama menunjukkan tidak adanya beda nyata pada uji DMRT pada taraf $5 \%$

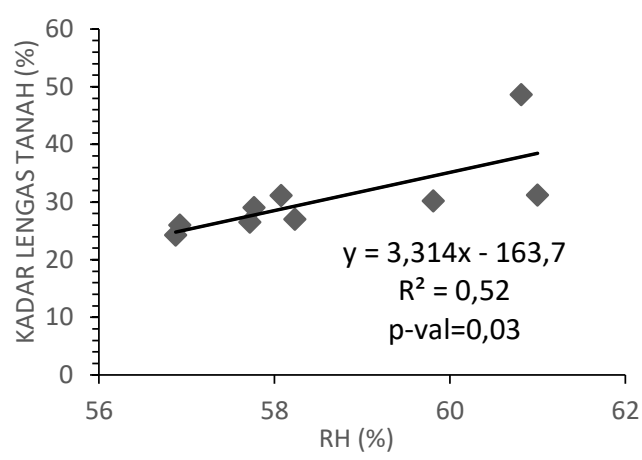

Gambar 1. Hubungan antara kelembapan udara dengan kadar lengas tanah

Tabel 7. Hasil analisis Aktivitas Nitrat Reduktase, Klorofil a, klorofil b, rasio klorofil b/a dan klorofil total tanaman sambung nyawa dalam berbagai fase agroforestri pada $16 \mathrm{mspt}$

\begin{tabular}{lclrlrlll}
\hline \multicolumn{1}{c}{ Fase Agroforestri } & \multicolumn{2}{c}{ Klorofil a } & \multicolumn{2}{c}{ Klorofil b } & \multicolumn{2}{c}{$\begin{array}{c}\text { Rasio } \\
\text { klorofil b/a }\end{array}$} & \multicolumn{2}{c}{$\begin{array}{c}\text { Klorofil } \\
\text { total }\end{array}$} \\
\hline Awal & 0,27 & $\mathrm{~b}$ & 0,22 & $\mathrm{~b}$ & 0,80 & $\mathrm{~b}$ & 0,49 & $\mathrm{~b}$ \\
Tengah & 0,30 & $\mathrm{ab}$ & 0,25 & $\mathrm{~b}$ & 0,83 & $\mathrm{~b}$ & 0,55 & $\mathrm{ab}$ \\
Lanjut & 0,36 & $\mathrm{a}$ & 0,39 & $\mathrm{a}$ & 1,07 & $\mathrm{a}$ & 0,75 & $\mathrm{a}$ \\
\hline Koefisien Keragaman (\%) & 11,80 & & 22,73 & & 10,17 & & 16,80 & \\
\hline
\end{tabular}

Keterangan: angka rerata yang diikuti huruf yang sama menunjukkan tidak adanya beda nyata pada uji DMRT pada taraf 5\%;

Hasil ini memiliki kesamaan dengan hasil penelitian Pradnyawan et. al. (2004) di mana kadar klorofil baik a ataupun b memiliki jumlah paling banyak pada kondisi naungan berat (70\%) dan sesuai dengan teori yang dinyatakan Amini dkk. (1990) bahwa proporsi klorofil b dalam tanaman di tempat ternaungi lebih tinggi daripada tanaman yang berada di daerah terik matahari. Begitupun dengan penelitian Rao dkk. (1997) yang membuktikan bahwa terdapat peningkatan kadar klorofil sebesar 64\% pada tanaman nilam yang ditanam di bawah naungan dibandingkan dengan yang ditanam di tempat terbuka. Devkota dan Jha (2010) juga melaporkan terjadinya peningkatan kadar klorofil pada tanaman pegagan yang ditanam di bawah naungan. Lakitan (2007) dalam Setiawan dan Sukamto (2016) menyatakan bahwa peningkatan kadar klorofil merupakan mekanisme tanaman untuk meningkatkan intersepsi cahaya pada kondisi ternaungi. Peningkatan kadar klorofil mendukung absorpsi radiasi aktif fotosintesis (PAR), yang mengindikasikan adaptasi tanaman terhadap rendahnya intensitas cahaya. 
Deborah Vegetalika. 2018. 7(3): 1-15

Tabel 8. Hasil analisis rerata luas daun, Indeks Luas Daun (ILD), Laju Asimilasi Bersih (LAB) pada 8-16 mspt

\begin{tabular}{|c|c|c|c|c|c|c|c|}
\hline \multirow{2}{*}{ Parameter } & \multicolumn{6}{|c|}{ Fase Agroforestri } & \multirow{2}{*}{$\mathrm{KK}(\%)$} \\
\hline & \multicolumn{2}{|c|}{ awal } & \multicolumn{2}{|c|}{ tengah } & \multicolumn{2}{|c|}{ lanjut } & \\
\hline Luas Daun $\left.8 \mathrm{mspt}^{1}\right)\left(\mathrm{cm}^{2}\right)$ & 1229 & $a$ & 2163,9 & a & 753 & $\mathrm{a}$ & 21,81 \\
\hline Luas Daun 12 mspt $\left.^{1}\right)\left(\mathrm{cm}^{2}\right)$ & 1703 & a & 3172 & a & 532 & a & 31,69 \\
\hline Luas Daun 16 mspt $\left.^{1}\right)\left(\mathrm{cm}^{2}\right)$ & 1873 & a & 2832 & a & 674 & a & 28,16 \\
\hline ILD 8 mspt $^{11)}$ & 0,77 & a & 1,35 & a & 0,47 & a & 21,81 \\
\hline ILD 12 mspt $^{1)}$ & 1,06 & a & 1,98 & a & 0,33 & a & 31,69 \\
\hline ILD 16 mspt $^{11)}$ & 1,17 & a & 1,77 & a & 0,42 & a & 28,16 \\
\hline LAB 8-12 $\left.\mathrm{mspt}^{1}\right)\left(\mathrm{g} / \mathrm{cm}^{2} / \mathrm{minggu}\right)$ & 0,17 & a & 0,12 & a & $-0,01$ & a & 7,47 \\
\hline LAB $12-16 \mathrm{mspt}^{1)}\left(\mathrm{g} / \mathrm{cm}^{2} / \mathrm{minggu}\right)$ & 0,23 & a & 0,15 & a & 0,23 & a & 11,92 \\
\hline
\end{tabular}

Keterangan: angka rerata yang diikuti huruf yang sama menunjukkan tidak adanya beda nyata pada uji DMRT pada taraf $5 \%$,

-1) menunjukkan data ditransformasi dengan bentuk $\sqrt{ }(\sqrt{ } X)$

${ }_{-2}^{-2}$ data ditransformasi dahulu dengan $\sqrt{ }(X+0,5)$

Biasanya semakin lanjut tingkat penaungan akan menyebabkan tanaman di bawahnya melakukan adaptasi berupa daun yang semakin luas dan tipis. Akan tetapi secara statistik fase perkembangan agroforestri tidak memberi pengaruh yang nyata pada luas daun tanaman sambung nyawa begitu pula indeks luas daunnya (Tabel 8). Gardner dkk. (2008) mengatakan bahwa luas daun memiliki kaitan yang erat dengan laju asimilasi bersih. Setelah dicari hubungannya dengan unsur mikroklimat, intensitas cahaya matahari dan kelembapan udara mempengaruhi laju asimilasi bersih pada 8-12 mspt (Gambar 2). LAB menggambarkan efisiensi fotosintesis dan merupakan laju penimbunan berat kering tanaman. Semakin banyak intensitas cahaya matahari yang diterima, stomata akan terbuka semakin lebar dan semakin panjang sehingga pertukaran $\mathrm{CO}_{2}$ meningkat, dan didukung oleh penurunan presentase kelembapan udara, menyebabkan laju transpirasi dan penyerapan unsur hara dari tanah ke dalam tanaman dengan gaya kapiler meningkat, semakin tinggi pula laju fotosintesis, maka laju penimbunan berat kering tanaman meningkat. Seperti yang dinyatakan oleh Rachmawati dkk (2009) laju transpirasi tinggi akan memacu akar menarik air lebih banyak sehingga meningkatkan pasokan nutrisi.
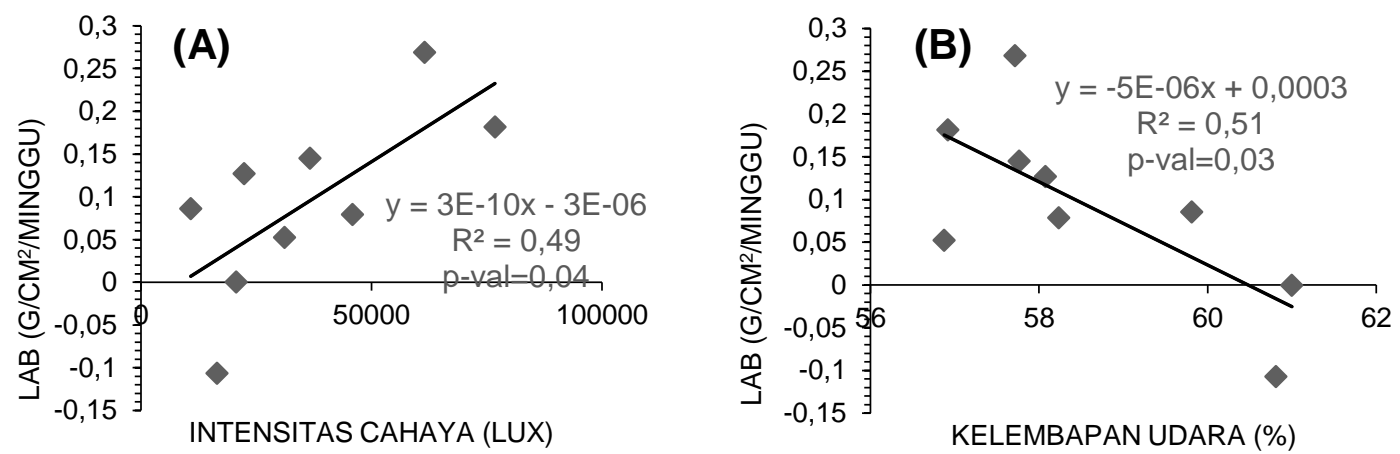

Gambar 2. Hubungan antara intensitas cahaya dengan laju asimilasi bersih umur 8-12 mspt (A), dan kelembapan udara dengan laju asimilasi bersih umur 8-12 mspt (B) 
Laju asimilasi bersih yang tidak dipengaruhi oleh fase perkembangan agroforestri menyebabkan berat segar maupun berat kering daun, akar, batang dan total tanaman sambung nyawa menunjukkan hasil yang tidak berbeda nyata. Fase perkembangan agroforestri secara statistik tidak memberi pengaruh nyata pada bobot segar maupun kering, akan tetapi intensitas cahaya matahari ternyata mempengaruhi bobot kering daun di umur 16 mspt (Gambar 3). Harjadi (1991) menyatakan, besarnya cahaya yang tertangkap pada proses fotosintesis menunjukkan biomassa, dan besarnya biomassa dalam jaringan tanaman mencerminkan bobot kering. Berdasarkan hal tersebut, biomassa atau fotosintat paling banyak tersimpan pada daun dalam kondisi intensitas cahaya matahari yang tinggi, dan fase agroforestri yang memiliki intensitas cahaya matahari yang tinggi yaitu pada agroforestri fase awal. Sebuah teori mengatakan bahwa penurunan intensitas cahaya yang diterima tanaman, mengakibatkan menurunnya nisbah berat kering pada semua organ tanaman. Produksi berat kering total tanaman yang ditanam di bawah naungan yang tinggi, jauh lebih rendah dari yang ditanam di bawah naungan yang rendah. Intensitas cahaya rendah yang dihasilkan naungan pada agroforestri lanjut mengakibatkan tanaman melakukan aktivitas respirasi yang lebih besar dari pada fotosintesis. Jika respirasi lebih besar dari fotosintesis maka akan mengurangi berat kering tanaman, sebab hasil berat kering merupakan keseimbangan antara fotosintesis dan respirasi (Gardner, 1995).

Tabel 9. Bobot segar batang, bobot segar daun, bobot segar akar, bobot segar total, bobot kering batang, bobot kering daun, bobot kering akar, bobot kering total tanaman sambung nyawa dalam berbagai fase agroforestri pada $16 \mathrm{mspt}$

\begin{tabular}{|c|c|c|c|c|c|c|c|}
\hline \multirow{2}{*}{ Parameter } & \multicolumn{6}{|c|}{ Fase Agroforestri } & \multirow[b]{2}{*}{ KK (\%) } \\
\hline & Awa & & Teng & & Lan & & \\
\hline Bobot segar batang ${ }^{1)}(\mathrm{g})$ & 56,06 & a & 90,18 & a & 19,63 & a & 21,00 \\
\hline Bobot segar daun ${ }^{1)}(\mathrm{g})$ & 120,78 & a & 158,48 & a & 39,55 & a & 22,63 \\
\hline Bobot segar akar' ${ }^{1}(\mathrm{~g})$ & 15,76 & a & 17,75 & a & 15,49 & a & 22,06 \\
\hline Bobot segar total ${ }^{11}(\mathrm{~g})$ & 192,60 & a & 266,4 & a & 74,70 & a & 23,50 \\
\hline Bobot kering batang ${ }^{1)}(\mathrm{g})$ & 10,61 & a & 17,96 & a & 3,23 & a & 21,00 \\
\hline Bobot kering daun ${ }^{1)}(\mathrm{g})$ & 13,12 & a & 15,34 & a & 3,40 & a & 22,63 \\
\hline Bobot kering akar ${ }^{1}(\mathrm{~g})$ & 5,09 & a & 6,09 & a & 4,66 & a & 15,23 \\
\hline Bobot kering total ${ }^{1}(\mathrm{~g})$ & 28,83 & a & 39,38 & a & 11,28 & a & 20,16 \\
\hline
\end{tabular}

Keterangan: ${ }^{1)}$ menunjukkan data ditransformasi dengan bentuk $\sqrt{ }(\sqrt{ } X)$

angka rerata yang diikuti huruf yang sama menunjukkan tidak adanya beda nyata pada uji DMRT pada taraf $5 \%$ 


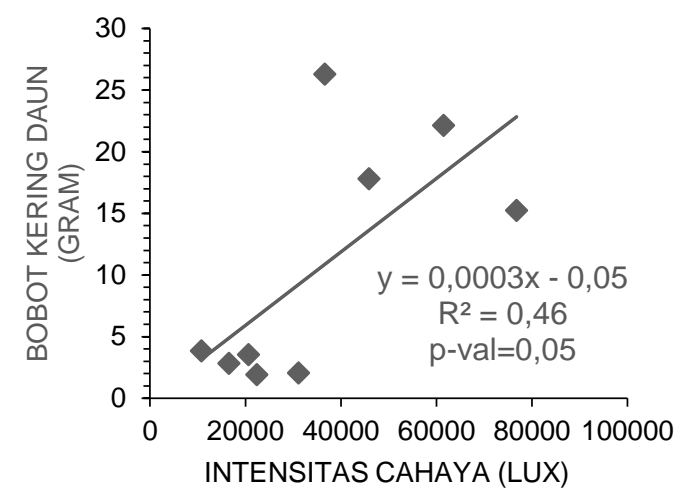

Gambar 3. Hubungan antara intensitas cahaya dengan bobot kering daun $16 \mathrm{mspt}$

Pengaruh intensitas cahaya pada bobot kering daun sambung nyawa umur 16 mspt secara tidak langsung turut berdampak pada bobot daun khas yang mencerminkan ketebalan daun. Terlihat pada Tabel 10 daun sambung nyawa umur 16 mspt pada agroforestri fase awal - yang mana memiliki intensitas cahaya matahari paling tinggi, lebih tebal daripada agroforestri fase lanjut, dan tidak terlalu berbeda dengan agroforestri fase tengah. Nirwan (2007) menyatakan perkembangan daun pada intensitas cahaya yang tinggi didominasi oleh peningkatan jumlah sel daripada ukuran sel sehingga daun menjadi tebal, sedangkan pada intensitas cahaya yang rendah peningkatan jumlah sel terhambat sehingga daun menjadi tipis. Penipisan daun pada intensitas cahaya rendah disebabkan oleh pengurangan lapisan palisade dan selsel mesofil. Struktur tersebut lebih berongga dan akan menambah efisiensi dalam menangkap energi radiasi cahaya untuk proses fotosintesis (Djukri dan Purwoko, 2003).

Tabel 10. Hasil analisis rerata Bobot Daun Khas daun sambung nyawa pada 8, 12, dan $16 \mathrm{mspt}$

\begin{tabular}{|c|c|c|c|c|c|c|}
\hline \multirow{2}{*}{ Fase Agroforestri } & \multicolumn{6}{|c|}{ Bobot Daun Khas $\left(\mathrm{g} / \mathrm{cm}^{2}\right)$} \\
\hline & $8 \mathrm{mspt}$ & & $12 \mathrm{mspt}$ & & $16 \mathrm{~ms}$ & \\
\hline awal & 0,44 & $a$ & 0,61 & a & 0,77 & $\mathrm{a}$ \\
\hline tengah & 0,38 & a & 0,47 & a & 0,55 & $a b$ \\
\hline lanjut & 0,36 & $\mathrm{a}$ & 0,43 & a & 0,52 & $\mathrm{~b}$ \\
\hline $\mathrm{KK}(\%)$ & 13,97 & & 21,18 & & 19,33 & \\
\hline
\end{tabular}

Keterangan: angka rerata yang diikuti huruf yang sama menunjukkan tidak adanya beda nyata pada uji DMRT pada taraf $5 \%$

Tabel 11 secara statistik menunjukkan nilai panjang tanaman, jumlah daun dan jumlah cabang yang tidak berbeda nyata. Ini dapat terjadi karena laju asimilasi bersih, laju pertumbuhan tanaman, serta bobot segar maupun kering tanaman yang juga tidak memiliki perbedaan nyata pada berbagai fase perkembangan agroforestri. Di sisi lain, intensitas cahaya matahari dan kelembapan udara dalam fase perkembangan agroforestri mempengaruhi jumlah percabangan sambung nyawa (Gambar 5). 
Deborah Gita Sakinah et al., / Vegetalika. 2018. 7(3): 1-15

Peningkatan intensitas cahaya matahari diikuti dengan peningkatan jumlah cabang, dan peningkatan kelembapan udara diikuti dengan penurunan jumlah cabang. Intensitas cahaya matahari memiliki hubungan negatif linier terhadap kelembapan udara, sehingga respon jumlah cabang terhadap kelembapan udara menjadi negatif linier pula. Salisbury dan Ross (1995) menyatakan bahwa penurunan jumlah cabang pada tumbuhan pada kondisi ternaungi dikarenakan tumbuhan menggunakan energi lebih banyak untuk menaikan apeks batangnya menuju puncak kanopi.

Tabel 11. Rerata panjang tanaman, jumlah daun, dan jumlah cabang tanaman sambung nyawa dalam berbagai fase agroforestri pada $16 \mathrm{mspt}$

\begin{tabular}{lccrrrr}
\hline \multicolumn{1}{c}{ Fase Agroforestri } & Panjang Tanaman $(\mathrm{cm})^{1)}$ & Jumlah Daun $^{1)}$ & \multicolumn{2}{c}{ Jumlah Cabang $^{1)}$} \\
\hline awal & 40,22 & $\mathrm{a}$ & 108,44 & $\mathrm{a}$ & 4,00 & $\mathrm{a}$ \\
tengah & 48,50 & $\mathrm{a}$ & 161,89 & $\mathrm{a}$ & 3,78 & $\mathrm{a}$ \\
lanjut & 27,17 & $\mathrm{a}$ & 38,44 & $\mathrm{a}$ & 2,34 & $\mathrm{a}$ \\
\hline Koefisien Keragaman (\%) & 21,00 & 22,63 & & 29,91 & \\
\hline
\end{tabular}

Keterangan: ${ }^{1)}$ menunjukkan data ditransformasi dengan bentuk $\sqrt{ }(\sqrt{ } \mathrm{X})$

angka rerata yang diikuti huruf yang sama menunjukkan tidak adanya beda nyata pada uji DMRT pada taraf $5 \%$.
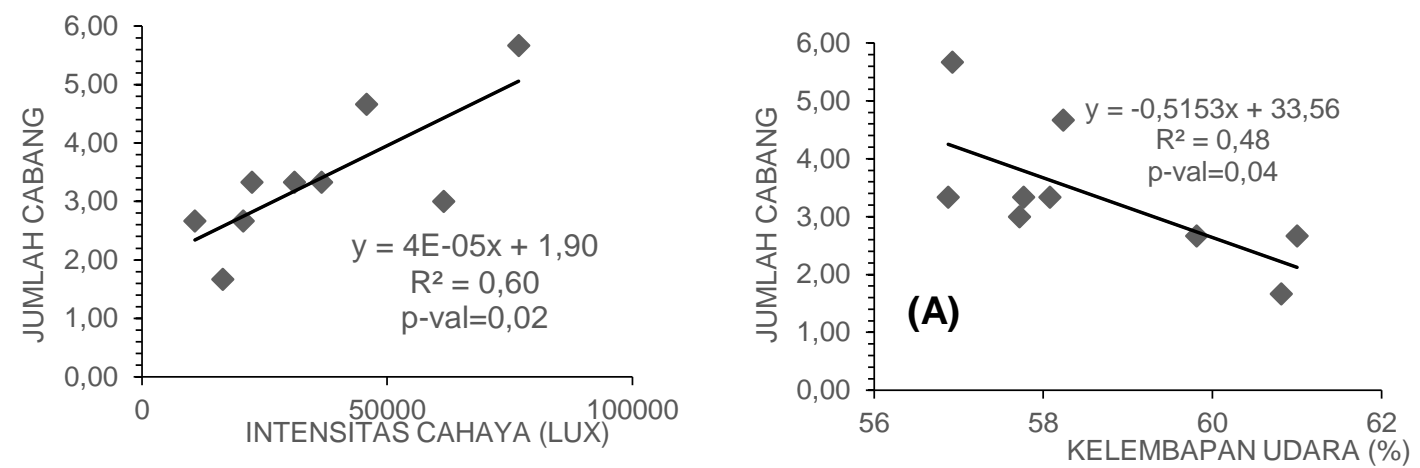

Gambar 4. Hubungan antara intensitas cahaya dengan jumlah cabang $(A)$ dan kelembapan udara dengan jumlah cabang (B)

Kualitas hasil tanaman sambung nyawa dilihat dari kadar flavonoid yang terdapat pada daun. Berdasarkan Tabel 12, kadar flavonoid pada daun sambung nyawa tidak dipengaruhi oleh fase perkembangan agroforestri. Ibrahim dan Jaafar (2011) menyatakan bahwa akumulasi metabolit sekunder kerap terjadi pada tanaman yang mengalami cekaman. Tidak adanya perbedaan nyata pada kadar flavonoid kali ini dapat disebabkan oleh kemampuan adaptasi sambung nyawa yang tinggi terhadap kondisi lingkungan fase perkembangan agroforestri yang berbeda sehingga produksi metabolit sekunder sebagai penangkal radikal bebas. Hal ini menunjukkan iklim mikro pada agroforestri masih berada pada batas yang mampu ditoleransi oleh sambung nyawa. 
Tabel 12. Hasil analisis kadar flavonoid tanaman sambung nyawa dalam berbagai fase agroforestri pada $16 \mathrm{mspt}$

\begin{tabular}{|c|c|c|}
\hline Fase Agroforestri & \multicolumn{2}{|c|}{ Flavonoid (\%b/b) ${ }^{1)}$} \\
\hline awal & 1,42 & $\mathrm{a}$ \\
\hline tengah & 1,72 & a \\
\hline lanjut & 1,18 & a \\
\hline
\end{tabular}

Koefisien Keragaman

21,00

Keterangan: ${ }^{1)}$ menunjukkan data ditransformasi dengan bentuk $\sqrt{ } X$

angka rerata yang diikuti huruf yang sama menunjukkan tidak adanya beda nyata pada uji DMRT pada taraf $5 \%$

Tabel 12 menunjukkan kadar flavonoid sambung nyawa pada agroforestri fase awal, tengah, akhir berturut-turut yaitu: 1,42, 1,72, dan 1,18\%b/b yang berarti memenuhi syarat farmakope herbal Indonesia untuk flavonoid total yang tidak boleh kurang dari $0,2 \%$ b/b (Kemenkes $\mathrm{RI}, 2010$ ). Kadar flavonoid sambung nyawa pada agroforestri fase awal lebih tinggi 0,24\% dari fase lanjut, dan 0,3\% lebih rendah dari fase tengah. Dibandingkan dengan standar mutu, sambung nyawa yang ditanam pada agroforestri awal, tengah, dan lanjut memiliki kadar flavonoid berturut-turut 7,1, 8,6, dan 5,9 kali lebih tinggi. Berdasarkan kadar flavonoid tersebut, sambung nyawa bisa dikatakan cukup adaptif dan bisa dibudidayakan pada sistem agroforestri.

\section{KESIMPULAN}

1. Tanaman sambung nyawa memiliki daya adaptasi yang cukup luas jika diusahakan dengan konsep agroforestri karena memiliki laju pertumbuhan, produktivitas, serta kualitas hasil yang sama ketika dibudidayakan pada agroforestri fase awal dengan penaungan $<50 \%$, fase tengah dengan penaungan $50-70 \%$, dan fase lanjut dengan penaungan $>70 \%$.

2. Kualitas daun sambung nyawa yang dihasilkan pada agroforestri fase awal, tengah, dan lanjut cukup baik dan dapat memenuhi standar Farmakope Herbal Indonesia, khususnya dari aspek kadar flavonoid. Secara berturut-turut kadar flavonoid daun sambung nyawa yang dihasilkan pada fase awal, tengah, dan lanjut adalah 1,42; 1,72; dan 1,18\%b/b.

\section{DAFTAR PUSTAKA}

Amini, S. Pramono, C.J. Soegihardjo, dan H. Hartiko. 1990. Biokimia Tumbuhan. Yogyakarta: PAU Bioteknologi UGM.

Badan Meteorologi Klimatologi dan Geofisika (BMKG). 2017. Mei-Juni-Juli Memasuki Awal Musim Kemarau 2017. <http://www.bmkg.go.id/berita/?p=mei-juni-juli- 
Deborah Gita Sakinah et al., / Vegetalika. 2018. 7(3): 1-15

memasuki-awal-musim-kemarau-2017\&lang=|D>. Diakses tanggal 16 November 2017.

Brady, N.C. 1974. The Nature and Property of Soils. 8th Ed. Macmillan Publishing Company, Inc., New York, N.Y.

Dainy, N.C. 2006. Produksi dan Kadar Flavonoid Daun Sambung Nyawa (Gynura procumbens[Lour]. Merr) pada Berbagai Tingkat Naungan dan Umur Pemangkasan. Departement Budi Daya Pertanian, Fakultas Pertanian. IPB. Bogor. Skripsi.

Devkota A dan PK Jha. 2010. Effects of Different Light Levels on the Growth Traits and Yield of Centella asiatica. Middle-East. Journal of Scientific Research 5(4): 226230.

Djukri, Purwoko, B S. 2003. Pengaruh naungan paranet terhadap sifat toleransi tanaman talas (Colocasia esculenta (L.) Schott). Ilmu Pertanian 10 (2): 17-25.

Gardner, F.P., R. B. Pearce, R. L. Mitchell. 1991. Fisiologi Tanaman Budidaya. Terjemahan: Herawati Susilo. Universitas Indonesia. Jakarta.

Gardner, F. P., R. B. Pearce, dan Roger L. Mitchell. 2008. Fisiologi tanaman budidaya. Diterjemahkan oleh Herawati Susilo. Penerbit UI Press, Jakarta.

Hani, A. dan P. Suryanto. 2014. Dinamika agroforestry tegalan di Perbukitan Menoreh, Kulon Progo, Daerah Istimewa Yogyakarta. JurnalPenelitian Kehutanan Wallacea 3(2): 119-128.

Hardjowigeno, S. 1995. Ilmu Tanah. Akademika Pressindo. Jakarta.

Harjadi, S.S. 1991. Pengantar Agronomi. Gramedia Pustaka Utama. Jakarta.

Hew, C.-S., Khoo, B.-Y., dan Gam, L.-H. 2013. The anti-cancer property of proteins extracted from Gynura procumbens (Lour.) Merr. doi: 10.1371/journal.pone.0068524

Ibrahim, M.H., H.Z.E. Jaafar. 2011. The influence of carbohydrate, protein and phenylanine ammonia lyase on up-regulation of production of secondary metabolites (Total phenolics and flavonoid) in Labisiapumila (Blume) fernvill (Kacip Fatimah) under high $\mathrm{CO}_{2}$ and different nitrogen levels. Molecules (16):4172-4190.

Kemenkes, R.I., 2010. Suplemen I Farmakope Herbal Indonesia, Jakarta, Kementerian Kesehatan Republik Indonesia.

Kurniawan, S., E. T. S. Putra, P. Suryanto, S. Waluyo. 2012. Pertumbuhan dan hasil kacang tanah (Arachis hypogaea L.) pada tiga fase agroforestri di zona Batur Agung, Gunung Kidul, Yogyakarta. Seminar Nasional Agroforestri III.

Lakitan B. 2007. Dasar-dasar fisiologi tumbuhan. Raja Grafindo Persada Jakarta. 203 hlm. Lakitan B. 1993. Dasar-dasar fisiologi tumbuhan. PT. Raja Grafindo Persada, Jakarta. 
MOA. Kementerian Pertanian Malaysia. 2015. Usahawan: Industri Herba. <http://www.moa.gov.my/web/guest/industri-herba.html>. Diakses 10 Oktober 2016.

Nirwan, G.M. \& Aziz, SA., 2007, Adaptasi Pertumbuhan dan Kadar Flavonoid daun dewa (Gynura pseudochina (L.) DC) asal kultur in vitro pada intensitas cahaya rendah, Prosiding Seminas Nasional Hibah Komepetitif Bogor 1-2 Agustus 2007.

Pradnyawan, S.W.H., W. Mudyantini, Marsusi. 2005. Pertumbuhan, Kadar Nitrogen, Klorofil dan Karotenoid Daun Gynura procumbens [Lour] Merr. pada Tingkat Naungan Berbeda. Biofarmasi 3 (1): 7-10

Rachmawati, F., Urifah, N., \& Wijayati, A., 2009, Biologi, Pusat Perbukuan Departemen Pendidikan Nasional, Jakarta.

Rao EVS, G Rao, MR Narayana, dan S Ramesh. 1997. Influence of Shade on Yield and Quality of Patchouli. Ind. Perf. 41: 164-166.

Salisbury, F.B. dan C.W. Ross. 1995. Fisiologi Tumbuhan. Jilid 3. Bandung: Penerbit ITB.

Setiawan dan Sukamto. 2016. Karakter morfologis dan fisiologis tanaman nilam di bawah naungan dan tanpa naungan. Buletin Penelitian Tanaman Rempah dan Obat 27(2): 137-148.

Suharmiati, dan Maryani. 2003. Khasiat dan Manfaat Daun Dewa dan Sambung Nyawa. Agromedia Pustaka. Jakarta.

Suprayogo, D., K. Hairiah, N. Wijayanto, Sunaryo dan M.V. Noordwijk. 2003. Bahan Ajaran Agroforestri 4. Peran Agroforestri pada Skala Plot: Analisis Komponen Agroforestri sebagai Kunci Keberhasilan atau Kegagalan Pemanfaatan Lahan. ICRAF SE Asia, Bogor.

Suryanto, Priyono., Tohari dan S.M. Sambas. 2005. Dinamika sistem berbagi sumberdaya (Resouces Sharing) dalam agroforestri: dasar pertimbangan penyusunan strategi silvikultur. UGM, Yogyakarta. IImu Pertanian Vol. 12 No.2 : 165 - 178.

Wijayanti, R. 2012. Budidaya sambung nyawa (Gynura procumbens (Lour.)Merr.) dan khasiatnya di PT. Indmira Yogyakarta. Tugas Akhir. Fakultas Pertanian. Universitas Sebelas Maret. Surakarta. <https://digilib.uns.ac.id> Diakses tanggal 29 Oktober 2016.

Winarto, W.P., Tim karyasari. 2003. Sambung Nyawa budidaya dan pemanfaatan untuk obat. Penebar Swadaya, Jakarta. 